\title{
A study on the effect of working capital management on profitability on Cement and Petrochemical industries: Evidence from Tehran Stock Exchange
}

\author{
Fatemeh Khaksarian*
}

M.Sc. of Finance, Department of Management, Adib Mazandaran University (AMU), Iran

\begin{tabular}{|c|c|}
\hline CHRON I CLE & A B S TRACT \\
\hline $\begin{array}{l}\text { Article history: } \\
\text { Received December 2, } 2013 \\
\text { Accepted } 8 \text { May 2014 } \\
\text { Available online } \\
\text { May 29 2014 } \\
\text { Keywords: } \\
\text { Tehran Stock Exchange } \\
\text { Working capital } \\
\text { Cement industry } \\
\text { Petrochemical industry }\end{array}$ & $\begin{array}{l}\text { This paper presents an empirical investigation to study the effect of working capital } \\
\text { management on profitability on Cement and Petrochemical industries. The study uses the } \\
\text { information of } 24 \text { firms from Cement industry and } 19 \text { firms from Petrochemical industry listed } \\
\text { on Tehran Stock Exchange. There are two independent variables including the ratio of current } \\
\text { assets on total assets as well as the ratio of current liabilities on total assets in this survey. In } \\
\text { addition, there are two dependent variables including return on assets (ROA) and Tobin's Q. } \\
\text { The study also considers firm size, sales' growth, financial leverage, gross domestic product } \\
\text { growth as control variables. Using stepwise regression technique, the study confirms a positive } \\
\text { and meaningful relationship between working capital criteria and profitability. In addition, the } \\
\text { study confirms that as the ratio of current assets to total assets increases, ROA and Tobin's Q } \\
\text { will be reduced, which means lower profitability would be resulted. In addition, as financial } \\
\text { leverage increases, ROA in both industries will reduce while Tobin's Q will increase in Cement } \\
\text { industry and will reduce in Petrochemical industry. }\end{array}$ \\
\hline
\end{tabular}

C 2014 Growing Science Ltd. All rights reserved.

\section{Introduction}

Working capital management plays essential role on corporate finance because it directly influences the liquidity and profitability of the firm (Raheman et al., 2010). Working capital normally deals with current assets and current liabilities and it is important for many reasons (Vishnani \& Shah, 2007). First, the current assets of a typical manufacturing firm are accounted for over half of its total assets and for a distribution firm, the figure is even higher. Excessive levels of current assets can easily yield in a firm's realizing a substandard return on investment (Raheman, \& Nasr, 2007). There are literally many studies associated with the effects of working capital on firms' profitability.

*Corresponding author. Tel: +989112538624

E-mail addresses: mana khaky@yahoo.com (F. Khaksarian)

(C) 2014 Growing Science Ltd. All rights reserved. doi: $10.5267 /$ j.msl.2014.5.031 
Deloof (2003) investigated the relationship between working capital management and corporate profitability for a sample of 1,009 large Belgian non-financial companies over the 1992-1996. They measured trade credit policy and inventory policy by number of days accounts receivable, accounts payable and inventories, and used the cash conversion cycle as a measure of working capital management. Their results recommended that managers could increase corporate profitability by reducing the number of days accounts receivable and inventories.

García-Teruel and Martínez-Solano (2007) provided some empirical evidence on the impacts of working capital management on the profitability of a sample of small and medium-sized Spanish companies. They reported that shortening the cash conversion cycle could improve the firm's profitability. Nazir and Afza (2009) studied the traditional relationship between working capital management policies and a firm's profitability. They gathered some panel data set for the period 1998-2005 and evaluated the effect of aggressive working capital investment and financing policies using return on assets as well as Tobin's q. The study detected that investors could give weight to the stocks of those firms that adopt an aggressive approach for managing their short-term liabilities. Ganesan (2007) performed an analysis on working capital management efficiency in telecommunication equipment industry. They examined the relationship between working capital management efficiency and profitability and found some evidence that even though "days working capital" was negatively associated with the profitability and it was not significantly influencing the profitability of firms in telecommunication equipment industry.

Baños-Caballero et al. (2010) analyzed the determinants of Cash Conversion Cycle (CCC) for smalland medium-sized companies. They reported that these firms had a target CCC length to which they tried to converge, and that they tried to adjust to their target very quickly. The results indicated that it was longer for older firms and firms with bigger cash flows. In contrast, companies with more growth opportunities, and with higher leverage, investment in fixed assets and return on assets had a more aggressive working capital policy.

\section{The proposed study}

This paper presents an empirical investigation to study the effect of working capital management on profitability on Cement and Petrochemical industries. There are four hypotheses associated with the proposed study of this paper as follows,

1. There is a meaningful relationship between Aggressive Investment Policy (AIP) of working capital and return on assets (ROA).

2. There is a meaningful relationship between Aggressive Investment Policy (AIP) of working capital and Tobin's Q.

3. There is a meaningful relationship between Aggressive Financial Policy (AFP) of working capital and return on assets (ROA).

4. There is a meaningful relationship between Aggressive Financial Policy (AFP) of working capital and Tobin's Q.

The study chooses firms based on some criteria to reach good quality results. First, the information of all firms must be available during the period of study. Second, all firms must have the same calendar and there must be no change on their fiscal year. The ticker symbol of all selected firms must be accepted on stock exchange prior to the period of study and finally, no holding or financial firm was considered for the proposed study.

The study uses the information of 24 firms from Cement industry and 19 firms from Petrochemical industry listed on Tehran Stock Exchange. There are two independent variables including the ratio of current assets on total assets as well as the ratio of current liabilities on total assets in this survey. In 
addition, there are two dependent variables including return on assets (ROA) and Tobin's Q. The study also considers firm size, sales' growth, financial leverage, gross domestic product growth as control variables. The study considers the following four regression models to examine the hypotheses of the survey,

$\mathrm{ROA}_{\mathrm{it}}=\alpha+\beta_{1}(\mathrm{TCA} / \mathrm{TA})_{\mathrm{it}}+\beta_{2}(\mathrm{SIZE})_{\mathrm{it}}+\beta_{3}(\mathrm{GROWTH})_{\mathrm{it}}+\beta_{4}(\mathrm{LVRG})_{\mathrm{it}}+\beta_{5}(\mathrm{GDPGR})_{\mathrm{it}}+\epsilon$

Tobin's qit $=\alpha+\beta_{1}(\text { TCA } / \text { TA })_{\text {it }}+\beta_{2}(\text { SIZE })_{\text {it }}+\beta_{3}(\text { GROWTH })_{\text {it }}+\beta_{4}(\text { LVRG })_{\text {it }}+\beta_{5}(\text { GDPGR })_{\text {it }}+\epsilon$

$\mathrm{ROA}_{\mathrm{it}}=\alpha+\beta_{1}(\mathrm{TCL} / \mathrm{TA})_{\mathrm{it}}+\beta_{2}(\mathrm{SIZE})_{\mathrm{it}}+\beta_{3}(\mathrm{GROWTH})_{\mathrm{it}}+\beta_{4}(\mathrm{LVRG})_{\mathrm{it}}+\beta_{5}(\mathrm{GDPGR})_{\mathrm{it}}+\epsilon$

Tobin's qit $=\alpha+\beta_{1}(\text { TCL } / \text { TA })_{\text {it }}+\beta_{2}(\text { SIZE })_{\text {it }}+\beta_{3}(\text { GROWTH })_{\text {it }}+\beta_{4}(\text { LVRG })_{\text {it }}+\beta_{5}(\text { GDPGR })_{\text {it }}+\epsilon$

where TCA, TA, SIZE, GROWTH, LVRG and GDPGR are total current assets, total assets, firm size, sales growth, financial leverage and GDP growth, respectively. In addition, $\alpha$ and $\beta_{\mathrm{i}} \mathrm{i}=1, \ldots .5$ are coefficients of the regression function and $\epsilon$ represents the residuals. Table 1 and Table 2 demonstrate some basic statistics associated with the proposed study.

\section{Table 1}

The summary of some basic statistics for Cement firms

\begin{tabular}{ccccccccc}
\hline Statistics & ROA & TOBIN q & AIP & AFP & SIZE & GROWTH & LVRG & GDPDR \\
\hline Mean & 0.1913 & 1.6953 & 0.2937 & 0.3437 & 13.795 & 0.2453 & 1.5091 & 4.2400 \\
Median & 0.1661 & 1.5650 & 0.2606 & 0.3146 & 13.806 & 0.1162 & 1.2672 & 5.0000 \\
Max & 0.5707 & 6.1441 & 0.8286 & 0.7654 & 15.413 & 5.2122 & 4.7739 & 6.6000 \\
Min & 0.0049 & 0.7443 & 0.0666 & 0.1156 & 12.369 & -0.6945 & 0.3503 & 0.8000 \\
Standard deviation & 0.1217 & 0.7760 & 0.1681 & 0.1166 & 0.5977 & 0.6177 & 0.9567 & 2.1041 \\
Skewness & 0.8959 & 2.7934 & 0.8053 & 1.1993 & 0.1293 & 4.7949 & 1.0856 & -0.5486 \\
Kurtosis & 3.6408 & 14.781 & 3.0040 & 4.8265 & 3.1698 & 37.287 & 4.0258 & 1.8642 \\
\hline
\end{tabular}

Table 2

The summary of some basic statistics for Petrochemical firms

\begin{tabular}{ccccccccc}
\hline Statistics & ROA & TOBIN q & AIP & AFP & SIZE & GROWTH & LVRG & GDPDR \\
\hline Mean & 0.1515 & 1.3670 & 0.614 & 0.4959 & 12.948 & 0.1632 & 2.2518 & 4.2400 \\
Median & 0.1170 & 1.1937 & 0.611 & 0.5139 & 12.819 & 0.1478 & 1.6473 & 5.0000 \\
Max & 0.5166 & 3.0745 & 1.452 & 0.8902 & 16.664 & 1.3988 & 9.7854 & 6.6000 \\
Min & -0.0695 & 0.8461 & 0.239 & 0.0570 & 9.5702 & -0.3400 & 0.2733 & 0.8000 \\
Standard deviation & 0.1316 & 0.4934 & 0.209 & 0.2134 & 1.7774 & 0.2683 & 2.0087 & 2.1064 \\
Skewness & 0.7429 & 1.6670 & 0.646 & -0.0666 & 0.3090 & 1.7181 & 1.5354 & -0.5486 \\
Kurtosis & 3.0027 & 5.4953 & 3.964 & 1.8765 & 2.2552 & 8.6028 & 4.9399 & 1.8642 \\
\hline
\end{tabular}

As we can observe from the results of Table 1 and Table 2, difference between means and medians are small and we can conclude that the data are normally distributed. Before taking any necessary action, we need to choose between random or fixed effect. Table 3 shows the results of our survey.

Table 3

The summary of random/fixed effect

\begin{tabular}{lcrrrrr}
\hline & \multicolumn{3}{c}{ Cement industry } & \multicolumn{3}{c}{ Petrochemical industry } \\
Effects Test & Statistic & d.f. & Prob. & Statistic & d.f. & Prob. \\
\hline Cross-section F & 3.98769 & $(23,91)$ & 0.0000 & 10.74368 & $(18,71)$ & 0.0000 \\
Cross-section Chi-square & 83.6494 & 23 & 0.0000 & 124.8994 & 18 & 0.0000 \\
\hline
\end{tabular}

The results of Table 3 indicate that we may choose random effect for the regression analysis associated with the Eq. (1). We have reached the same conclusion for Eqs. (2-4) and the results are not given in this section. 


\section{The results}

In this section, we present details of our findings on testing four hypotheses of the survey.

\subsection{The first hypothesis: The effect of AIP on ROA}

The first hypothesis of the survey investigates the effects of AIP on ROA. Table 4 shows details of the regression analysis.

\section{Table 4}

The summary of regression analysis on Eq. (1) in Cement industry

\begin{tabular}{ccccc}
\hline Variable & Coefficient & Standard deviation & t-value & P-Value \\
\hline C & -0.168258 & 0.197622 & -0.851417 & 0.3963 \\
AIP & 0.332213 & 0.054772 & 6.065420 & 0.0000 \\
SIZE & 0.025386 & 0.013744 & 1.847089 & 0.0673 \\
GROWH & 0.002791 & 0.009534 & 0.292735 & 0.7703 \\
LVRG & -0.049301 & 0.008737 & -5.642994 & 0.0000 \\
GDPGR & -0.003424 & 0.002678 & -1.278839 & 0.2036 \\
\hline
\end{tabular}

R-Square $=0.5186$ Adjusted R-Square $=0.4975$ F-value $=24.76$ P-value $=0.000 \mathrm{D}$-W $=1.24$

As we can observe from the results of Table 4, the coefficient of AIP is statistically meaningful when the level of significance is one percent. F-value is equal to 24.76 with p-value $=0.000$. Adjusted RSquare is equal to 0.52 , which means the independent variables describe $52 \%$ of the changes on dependent variable. Based on the results, we may conclude that there was a positive and meaningful relationship between AIP and ROA in Cement industry. Table 5 shows details of our findings on petrochemical industry.

Table 5

The summary of regression analysis on Eq. (1) in Petrochemical industry

\begin{tabular}{ccccc}
\hline Variable & Coefficient & Standard deviation & t-value & P-Value \\
\hline C & -0.415802 & 0.148596 & -2.798198 & 0.0063 \\
AIP & 0.184114 & 0.052108 & 3.533288 & 0.0007 \\
SIZE & 0.038334 & 0.010510 & 3.647346 & 0.0004 \\
GROWTH & 0.041070 & 0.024673 & 1.664540 & 0.0995 \\
LVRG & -0.027768 & 0.005797 & -4.790483 & 0.0000 \\
GDPGR & 0.003234 & 0.002904 & 1.113699 & 0.2684 \\
\hline
\end{tabular}

$\mathrm{R}$-Square $=0.4729$ Adjusted R-Square $=0.4432 \mathrm{~F}$-value $=15.97 \mathrm{P}$-value $=0.000 \mathrm{D}-\mathrm{W}=0.99$

The results of Table 5 are consistent with our findings on Cement industry but the coefficient of AIP is smaller than what we have in Cement industry. Therefore, we can confirm the first hypothesis in Petrochemical industry.

\subsection{The second hypothesis: The effect of AIP on Tobin's $Q$}

The second hypothesis of the survey investigates the effects of AIP on Tobin's Q. Table 6 demonstrates details of the regression analysis.

Table 6

The summary of regression analysis on Eq. (2) in Cement industry

\begin{tabular}{|c|c|c|c|c|}
\hline Variable & Coefficient & Standard deviation & t-value & P-Value \\
\hline $\mathrm{C}$ & -9.145007 & 1.523662 & -6.001992 & 0.0000 \\
\hline AIP & 1.412068 & 0.407938 & 3.461472 & 0.0008 \\
\hline SIZE & 0.728658 & 0.107621 & 6.770598 & 0.0000 \\
\hline GROWTH & 0.013947 & 0.060389 & 0.230955 & 0.8178 \\
\hline LVRG & 0.114085 & 0.061216 & 1.863641 & 0.0649 \\
\hline GDPGR & 0.046662 & 0.016719 & 2.791033 & 0.0062 \\
\hline
\end{tabular}


As we can observe from the results of Table 6, the coefficient of AIP is statistically meaningful when the level of significance is one percent. F-value is equal to 8.62 with p-value $=0.000$. Adjusted RSquare is equal to 0.24 , which means the independent variables describe $24 \%$ of the changes on dependent variable. Based on the results, we may conclude that there was a positive and meaningful relationship between AIP and Tobin's Q in Cement industry. Table 7 shows details of our findings on petrochemical industry.

\section{Table 7}

The summary of regression analysis on Eq. (2) in Petrochemical industry

\begin{tabular}{|c|c|c|c|c|}
\hline Variable & Coefficient & Standard deviation & t-value & P-Value \\
\hline $\mathrm{C}$ & -2.311584 & 0.571586 & -4.044155 & 0.0001 \\
\hline AIP & 0.571509 & 0.219702 & 2.601290 & 0.0109 \\
\hline SIZE & 0.239321 & 0.039890 & 5.999548 & 0.0000 \\
\hline GROWTH & 0.088785 & 0.108018 & 0.821944 & 0.4133 \\
\hline LVRG & -0.020470 & 0.024488 & -0.835917 & 0.4054 \\
\hline GDPGR & 0.061412 & 0.012691 & 4.838827 & 0.0000 \\
\hline
\end{tabular}

$\mathrm{R}$-Square $=0.427$ Adjusted R-Square $=0.457 \mathrm{~F}$-value $=15.01 \mathrm{P}$-value $=0.000 \mathrm{D}-\mathrm{W}=1.21$

The results of Table 7 also confirm that AIP influences on Tobin's Q but the impact is smaller compared with Cement industry. Therefore, the second hypothesis of the survey has been confirmed.

\subsection{The third hypothesis: The effect of AFP on ROA}

The third hypothesis of the survey investigates the effects of AFP on ROA. Table 8 demonstrates details of the regression analysis.

Table 8

The summary of regression analysis on Eq. (3) in Cement industry

\begin{tabular}{ccccc}
\hline Variable & Coefficient & Standard deviation & t-value & P-Value \\
\hline C & -0.091503 & 0.253127 & -0.361489 & 0.7184 \\
AFP & -0.054455 & 0.074027 & -0.735606 & 0.4635 \\
SIZE & 0.030329 & 0.017796 & 1.704220 & 0.0911 \\
GROWTH & 0.002792 & 0.009598 & 0.290858 & 0.7717 \\
LVRG & -0.067490 & 0.009602 & -7.029020 & 0.0000 \\
GDPGR & -0.003703 & 0.002681 & -1.381175 & 0.1699 \\
\hline
\end{tabular}

$\mathrm{R}$-Square $=0.372$ Adjusted R-Square $=0.342 \mathrm{~F}$-value $=13.52 \mathrm{P}$-value $=0.000 \mathrm{D}-\mathrm{W}=1.28$

The results of Table 8 do not confirm any meaningful relationship between AFP and ROA. Therefore, the third hypothesis is not confirmed in Cement industry. Table 9 shows details of our findings for Petrochemical industry.

Table 9

The summary of regression analysis on Eq. (3) in Petrochemical industry

\begin{tabular}{ccccc}
\hline Variable & Coefficient & Standard deviation & t-value & P-Value \\
\hline C & -0.066728 & 0.139023 & -0.479976 & 0.6324 \\
AFP & -0.218204 & 0.064709 & -3.372092 & 0.0011 \\
SIZE & 0.026760 & 0.009947 & 2.690117 & 0.0085 \\
GROWTH & 0.081252 & 0.023897 & 3.400020 & 0.0010 \\
LVRG & -0.012267 & 0.007086 & -1.731161 & 0.0869 \\
GDPGR & -0.001329 & 0.003049 & -0.435845 & 0.6640 \\
\hline R-Square $=0.437$ Adjusted R-Square $=0.467$ F-value $=15.64$ P-value $=0.000$ D-W $=1.49$ & &
\end{tabular}

The results of Table 9 are also consistent with previous results and we cannot confirm the third hypothesis for Petrochemical industry.

\subsection{The fourth hypothesis: The effect of AFP on Tobin's $Q$}

The third hypothesis of the survey investigates the effects of AFP on Tobin's Q. Table 10 demonstrates details of the regression analysis. 
Table 10

The summary of regression analysis on Eq. (4) in Cement industry

\begin{tabular}{ccccc}
\hline Variable & Coefficient & Standard deviation & t-value & P-Value \\
\hline C & -13.42756 & 1.779289 & -7.546588 & 0.0000 \\
AFP & 1.369660 & 0.483951 & 2.830161 & 0.0055 \\
SIZE & 1.053923 & 0.125390 & 8.405192 & 0.0000 \\
GROWTH & 0.023233 & 0.058506 & 0.397108 & 0.6920 \\
LVRG & -0.030672 & 0.064528 & -0.475329 & 0.6355 \\
GDPGR & 0.036180 & 0.016226 & 2.229805 & 0.0277 \\
\hline
\end{tabular}

$\mathrm{R}$-Square $=0.370$ Adjusted R-Square $=0.343 \mathrm{~F}$-value $=13.43$ P-value $=0.000 \mathrm{D}-\mathrm{W}=1.28$

The results of Table 10 confirm that AFP influences positively on Tobin's Q in Cement industry. Table 11 demonstrates the results of our survey for testing the fourth hypothesis in Petrochemical industry.

\section{Table 11}

The summary of regression analysis on Eq. (4) in Petrochemical industry

\begin{tabular}{ccccc}
\hline Variable & Coefficient & Standard deviation & t-value & P-Value \\
\hline C & -1.191049 & 0.519851 & -2.291135 & 0.0243 \\
AFP & -0.402857 & 0.282586 & -1.425606 & 0.1575 \\
SIZE & 0.191153 & 0.036309 & 5.264601 & 0.0000 \\
GROWTH & 0.197078 & 0.107839 & 1.827515 & 0.0710 \\
LVRG & 0.012911 & 0.030732 & 0.420125 & 0.6754 \\
GDPGR & 0.052256 & 0.013665 & 3.823990 & 0.0002 \\
\hline
\end{tabular}

$\mathrm{R}$-Square $=0.426$ Adjusted R-Square $=0.394 \mathrm{~F}$-value $=13.22$ P-value $=0.000 \mathrm{D}-\mathrm{W}=1.32$

The results of Table 11 are not consistent with findings of Cement industry. In other words, there is not any meaningful relationship between AFP and Tobin's Q in Petrochemical industry.

\section{Conclusion}

In this paper, we have presented an empirical investigation to study the effect of AIP as well as AFP on ROA and Tobin's Q. The study has confirmed a positive relationship between working capital criteria and profitability. In addition, the study has confirmed that as the ratio of current assets to total assets increases, ROA and Tobin's Q would be reduced, which means lower profitability would be resulted. In addition, as financial leverage increases, ROA in both industries will reduce while Tobin's Q will increase in Cement industry and will reduce in Petrochemical industry.

\section{References}

Baños-Caballero, S., García-Teruel, P. J., \& Martínez-Solano, P. (2010). Working capital management in SMEs. Accounting \& Finance, 50(3), 511-527.

Deloof, M. (2003). Does working capital management affect profitability of Belgian firms?. Journal of Business Finance \& Accounting, 30(3-4), 573-588.

García-Teruel, P. J., \& Martínez-Solano, P. (2007). Effects of working capital management on SME profitability. International Journal of Managerial Finance,3(2), 164-177.

Ganesan, V. (2007). An analysis of working capital management efficiency in telecommunication equipment industry. Rivier Academic Journal, 3(2), 1-10.

Nazir, M. S., \& Afza, T. (2009). Impact of aggressive working capital management policy on firms' profitability. IUP Journal of Applied Finance, 15(8), 19-30

Raheman, A., \& Nasr, M. (2007). Working capital management and profitability-case of Pakistani firms. International Review of Business Research Papers, 3(1), 279-300.

Raheman, A., Afza, T., Qayyum, A., \& Bodla, M. A. (2010). Working capital management and corporate performance of manufacturing sector in Pakistan. International Research Journal of Finance and Economics, 47(1), 156-169.

Vishnani, S., \& Shah, B. K. (2007). Impact of working capital management policies on corporate performance-An empirical study. Global Business Review, 8(2), 267-281. 